PRIMANOMICS : JURNAL EKONOMI DAN BISNIS - VOL. 17. NO. 2 (2019)

Versi Online Tersedia di : https://jurnal.ubd.ac.id/index.php/ds

| 1412-632X (Cetak) | 2614-6789 (Online) |

\title{
Analisis Strategi Bersaing Perusahaan Yang Bergerak Dibidang Logistik Di Jakarta
}

\author{
Puti Lenggo Ginny \\ Universitas Buddhi Dharma, Banten, Indonesia
}

\begin{abstract}
Abstrak
Indonesia telah mencatat pertumbuhan ekonomi sebesar $12,3 \%$ selama periode 2009 sampai dengan 2014 yang mana salah satu faktor pendorong pertumbuhan ini berasal dari sektor logistik. Sebagai salah satu perusahaan BUMN yang bergerak di bidang logistik, Perusahaan logistik mengembangkan unit bisnis baru yang memberikan jasa dalam bidang kurir dan pengiriman dengan tujuan untuk mempertahankan eksistensi dan memperluas pangsa pasar dalam industri logisik. Beberapa kendala ditemukan dalam operasional unit bisnis tersebut baik yang bersifat internal maupun eksternal yang pada akhirnya berakibat tidak bertumbuhnya kontribusi laba terhadap perusahaan induk.

Penelitian ini bertujuan untuk menganalisis strategi bersaing pada perusahaan logistik dengan melakukan analisis faktor internal dan faktor eksternal dengan menggunakan metode deskriptif kualitatif. Sumber daya, kapabilitas dan kompetensi inti digunakan sebagai analisis faktor internal dan analisis lingkungan makro dan Porter's Five Forces untuk analisis faktor eksternal. Disamping itu, penelitian ini akan memberikan rekomendasi dalam memformulasikan strategi bersaing yang tepat bagi perusahaan guna memenangkan kompetisi dalam industri logistik dengan menggunakan analisis SWOT dan strategi generik.

Hasil yang diperoleh dari analisis yang dilakukan yaitu perusahaan logistik memiliki peluang dan ancaman yang relatif cukup besar dalam industri logistik dan beberapa kekuatan dan kelemahan pada sisi internal yang harus ditinjau kembali oleh perusahaan. Oleh karena itu, rekomendasi strategi yang tepat bagi perusahaan yaitu strategi fokus pada diferensiasi, menentukan target pasar yang lebih spesifik dalam pengembangan bisnis yang ada, menetapkan geografis dalam kegiatan operasional, memiliki asset yang cukup dan memadai untuk menunjang kegiatan operasional dan pemanfaatan yang optimal atas pengalaman dan reputasi perusahaan di dalam industri logistik.
\end{abstract}

\section{Kata kunci : Industri Logistik, Deskriptif Kualitatif, Strategi Bersaing dan Strategi Fokus diferensiasi}




\begin{abstract}
During 2009 to 2014, Indonesia has recorded 12,3\% for economic growth which is one of these growth drivers are from the logistic sector. Recently logistic company, a logistic state-owned company, has developed a new business unit that giving the services in courier delivery services with purposing to maintain existency and enlarge market share on logistic industry. Unfortunately in progressing, these new unit business has been found several constrains both of internal and external. Those constraints has impacted to company which is shown there is no profit contribution to company.

Aim of this research is to analyze the competitive strategy at logistic company by descriptive method through in depth interview. Internal factor analysis are performed by using resources, capabilities and core competencies, meanwhile macro environment analysis and Porter's Five Forces are for external factor analysis. This research will provide the recommendations in formulating the right competitive strategy to logistic company for winning the competition on logistic industry by using SWOT and generic strategy.

The results of this research have shown that there are opportunities and threats in logistics industry and also some of the strengths and weaknesses internal that should be reviewed by logistic company. Therefore, this research recommends a strategy focus on differentiation, determining more specific market targets in the development of existing businesses, geographical setting in operational activities, having adequate and sufficient assets to support operational activities and optimizing utilization of the company's experience and reputation in the logistics industry for company as the right competitive strategy to implement.
\end{abstract}

Key Words : Logistic Industry, Qualitative Descriptive, Competitive Strategy and Strategy Focus on Differentiation 


\section{PENDAHULUAN}

Perkembangan sektor industri Logistik di Indonesia yang mengalami pasang surut menjadi penting untuk merumuskan kebijakan yang mampu mendorong peranan sektor industri logistik dalam pembentukan GDP. Growth Domestic Product (GDP) Indonesia telah mencatat pertumbuhan ekonomi yang stabil selama periode 2009 sampai 2014. Seperti dilihat pada gambar 1.1 dengan CAGR (Compound Annual Growth Rate) sebesar 12,3\% selama periode 2009 sampai 2014 karena konsumsi domestik yang kuat, pentingnya relatif terbatas ekspor Indonesia terhadap perekonomian nasional dan kepercayaan pasar yang tinggi. Pertumbuhan ekonomi lambat pada tahun 2014 sekitar 5,2\% disebabkan oleh kombinasi dari ketidakpastian global dan program Federal Reserve mengakibatkan arus keluar modal dari negara berkembang.

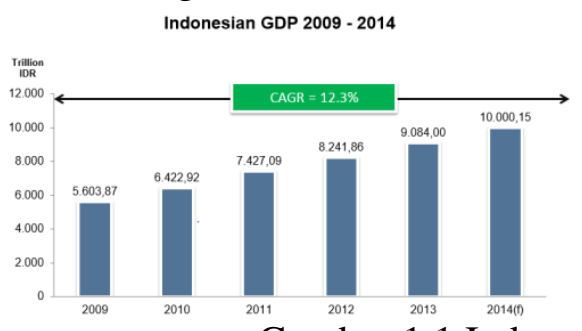

Gambar 1.1 Indonesia GDP Periode 2009 sampai 2014

Sumber: Central Statistics Bureau.Analysis by Frost \& Sullivan

Dalam perdagangan Internasional, Indonesia memiliki keunggulan komparatif yang sangat banyak antara lain sumberdaya alam yang berlimpah dan upah tenaga kerja yang relatif rendah dibandingkan dengan negara lain. Indonesia merupakan negara dengan jumlah penduduk besar yang dapat dijadikan pasar potensial bagi produk-produk domestik. Akan tetapi, keunggulan komparatif yang Indonesia miliki tidak diikuti dengan keunggulan kompetitif. Daya saing produk Indonesia masih sangat lemah apabila dibandingkan dengan produk dari negara lain. Indeks daya saing Indonesia yang dirilis oleh Global Competitiveness Index (GCI) tahun 2010 menunjukkan bahwa Indonesia masih berada di peringkat 44 dari 139 negara. Di antara negara anggota ASEAN, Indonesia berada pada urutan ke-5 setelah Singapura (3), Malaysia (26), Brunei (28), Thailand (38), dan berada di atas peringkat Vietnam (59), Filipina (85), dan Kamboja (109). Hal ini menunjukkan bahwa dalam kawasan regional yang memiliki produk atau komoditi unggulan yang relatif sama Indonesia masih belum mampu bersaing dengan negara-negara tetangga.

Sektor jasa logistik memiliki peranan penting dalam distribusi barang dan perdagangan di Indonesia. Executive Board Asosiasi Logistik Indonesia, Hotemo Lembito mengungkapkan bahwa logistics business is too huge to be missed. Hoetomo menyebut sejumlah peluang yang bisa dimanfaatkan para pemain di bisnis logistik, masih besarnya ruang untuk inovasi dan perbaikan mengingat biaya logistik berkontribusi sebesar $26 \%$ dari pertumbuhan domestik bruto (PDB) nasional. Sebuah kontribusi biaya yang begitu besar, mengingat biaya logistik negara-negara maju hanya berkontribusi sebesar $7 \%$ saja dari PDB mereka. Artinya, begitu mereka bisa bergerak lebih efisien, maka kemenangan akan ada di tangan mereka. Bisnis logistik juga merupakan bisnis yang memiliki pertumbuhan sangat cepat, dikisaran $15 \%$ sampai $20 \%$ per tahunnya, khususnya di kawasan luar pulau Jawa atau 
di luar Jakarta (Wibowo, 2017). ${ }^{1}$ Berdasarkan Gambar 1.2, dapat dilihat bahwa setiap tahunnya transportasi dan pasar logistik Indonesia mengalami peningkatan. Grafik batang yang berwarna hijau merepresentasikan jumlah biaya yang tersembunyi yang berkaitan dengan sistem logistik. Terlihat pula bahwa setiap tahunnya mengalami kenaikan. Biaya tersembunyi tersebut terdiri atas biaya pergudangan, administrasi, dan biaya persediaan. Pada grafik batang yang berwarna orange merepresentasikan jumlah pelaku logistik yang juga mengalami penambahan. Untuk laju pertumbuhan majemuk tahunan (CAGR) dari tahun 2009 sampai 2014 meningkat sebesar 13.7\%. Oleh karena itu, dapat dikatakan bahwa logistik Indonesia sudah mengalami perbaikan dalam berbagai sektor dan penambahan pelaku jasa logistik.

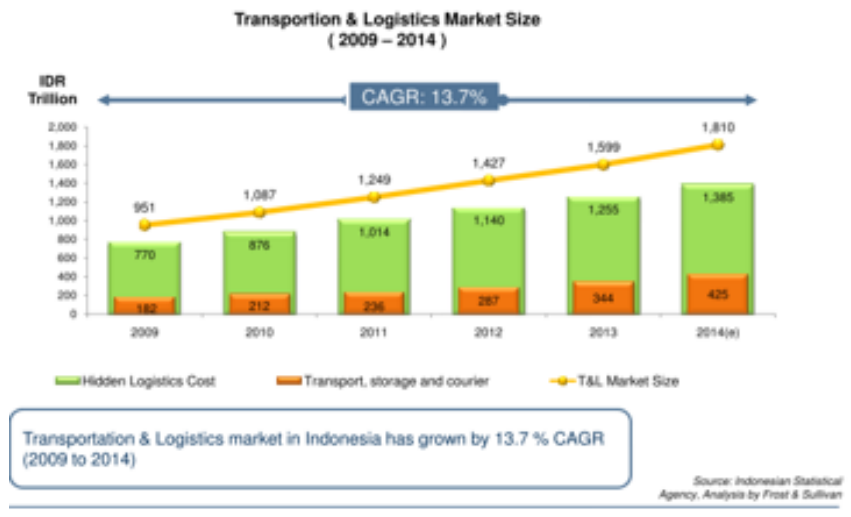

Gambar Transportation \& Logistic Market Size (2009-2014)

Sumber : Indonesian Statistical Agency, Analysis by Frost \& Sullivan

Frost \& Sullivan memprediksi industri logistik Indonesia tumbuh 14,7\% menjadi Rp 1.816 triliun pada tahun 2014, dibandingkan dengan perkiraan Rp 1.583 triliun setahun yang lalu karena pertumbuhan di sektor jasa dan peningkatan konsumsi pribadi rumah tangga. Gopal R, Vice President Global, Transportation \& Logistics Practice, Frost \& Sullivan mengungkapkan bahwa relokasi dan aliran modal yang kuat diharapkan dapat mendorong kegiatan manufaktur dan meningkatkan permintaan logistik di Indonesia. Untuk periode 2013 sampai 2017, diprediksi pasar transportasi dan logistik di Indonesia dapat tumbuh 14,8\% (Frost \& Sullivan, 2014). ${ }^{2}$

Dengan adanya prediksi pasar transportasi dan logistik untuk periode 2013 sampai 2017 yang akan meningkat, persaingan antar perusahaan logistik pun makin ketat. Peluang bisnis logistik di Indonesia masih terbuka lebar. Ini sejalan dengan semakin banyaknya perusahaan baik bertaraf nasional maupun multinasional yang memakai jasa pihak ketiga untuk menangani aktivitas logistiknya. Kondisi itulah yang memicu persaingan di industri logistik. Tidak hanya antar pemain logistik asing, melainkan juga dengan perusahaan logistik lokal yang berlomba-lomba menawarkan pelayanan terbaiknya termasuk perusahaan logistik BUMN. Hal ini menuntut perusahaan agar dapat lebih melakukan inovasi dalam melakukan usaha dan memperluas jaringannya. Perusahaan dituntut untuk dapat memiliki value added dalam setiap bidang usahanya agar dapat bersaing.

Sekarang ini jasa logistik perlu mempersiapkan diri menghadapi persaingan antar kompetitor jasa logistik penyedia lainnya, maka perusahaan harus jeli dalam melihat peluang pasar serta keinginan dan kebutuhan dari pelanggan. Perusahaan jasa logistik harus dapat

\footnotetext{
${ }^{1}$ Wibowo, Dhiyan W.2014. Bisnis Logistik, Peluang atau Tantangan. http://ali.web.id/press_release.php?id=37 diakses 1 April 2017

${ }^{2}$ Melihat http://www.frost.com/prod/servlet/press-release.pag?docid=290094205\# diakses pada tanggal 4 Januari 2017
} 
memberikan jasa berkualitas dengan biaya yang lebih murah dan pelayanan yang lebih baik serta dapat memuaskan kebutuhan pelanggan sehingga timbul loyalitas. Jasa logistik merupakan perusahaan yang berorientasi ke masa yang akan datang, maka perusahaan harus berorientasi pada keinginan konsumennya tidak semata mata untuk mendapatkan laba, mengingat sekarang ini konsumen sudah semakin kritis terhadap kebutuhan dan keinginan mereka. Pada gambar 1.3 dan gambar 1.4 dapat dilihat perusahaan yang menduduki urutan pertama sebagai pemimpin pasar dalam industri logistik Indonesia yaitu Ceva. Perusahaan bahkan meninggalkan dua pesaing terdekat mereka, Damco Indonesia \& GoTrans Logistics, jauh di belakang. Sebagian besar perusahaan, bersaing sangat ketat dengan satu sama lain, seperti yang ditunjukkan oleh konsentrasi tinggi dari gelembung di sudut kiri bawah dari grafik. Banyak perusahaan juga menemukan waktu yang sulit untuk menghasilkan laba bersih yang tinggi, meskipun mampu menghasilkan pendapatan yang tinggi. Contoh perusahaan dalam kategori ini adalah Damco Indonesia, Pantos Logistik, Puninar Jaya, dan Serasi Logistik. Sedangkan untuk perusahaan logistik BUMN menduduki peringkat ke 11 dalam industri logistik Indonesia.

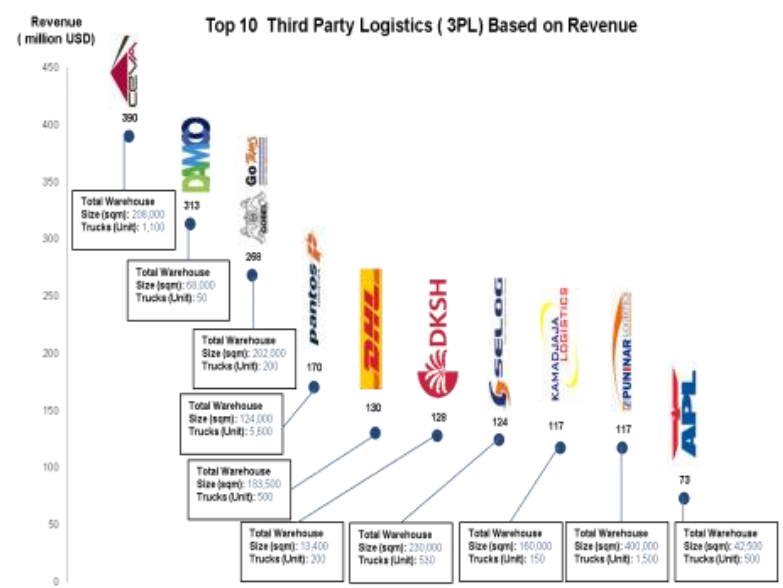

Gambar Top 10 Third Party Logistics (3PL) Based on Revenue

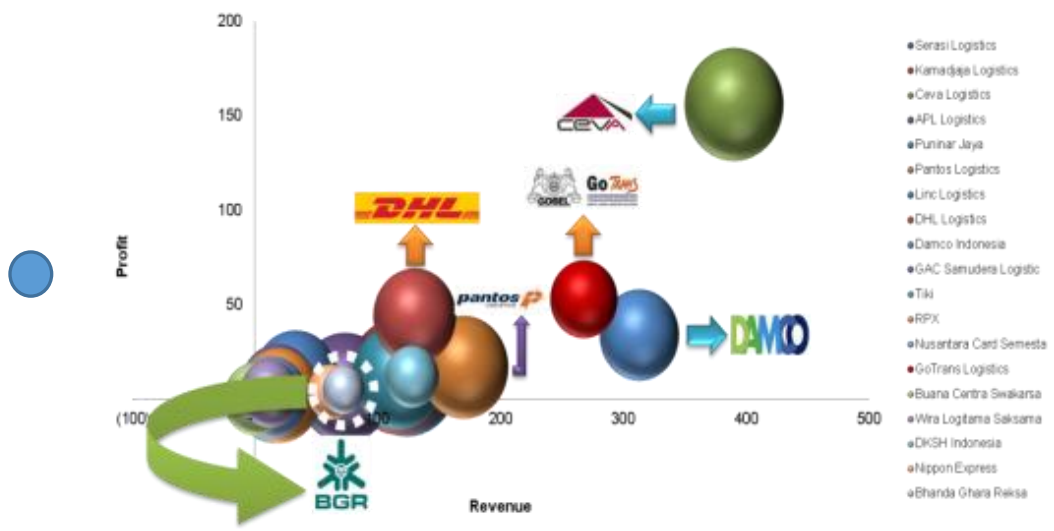

Gambar Posisi Perusahaan Logistik BUMN di Industri Logistik Indonesia Sumber: Primary research interview. Analysis by Frost \& Sullivan

Perusahaan logistik yang merupakan perusahaan BUMN, mengemban misi turut menunjang kebijaksanaan pemerintah dan membantu pelaku bisnis dan industri, khususnya dibidang penyelenggaraan jasa penyewaan dan pengelolaan ruangan serta proses pengiriman 
barang, dengan tetap memperhatikan prinsip-prinsip pengelolaan usaha yang sehat dan undang-undang perseroan terbatas. Dengan maraknya perkembangan di bisnis logistik dan perusahaan menempati urutan ke 11 dalam industri logistik Indonesia, perusahaan dalam perkembangannya selalu berusaha untuk mempertahankan keunggulan bisnisnya dalam meningkatkan nilai perusahaan tersebut.

Perusahaan logistik bergerak di sektor jasa pergudangan dengan melakukan kegiatan penyimpanan, pengelolaan, distribusi saprotan milik PT Pusri dan kegiatan freight forwading. Dengan perkembangan bisnis logistik yang sangat cepat, perusahaan meluncurkan bisnis unit yang diharapkan dapat mempertahankan eksistensi perusahaan yaitu jasa pengiriman dokumen dan paket X Ekpress . Jasa layanan pengiriman cepat atau kurir diluncurkan agar perusahaan dapat bersaing di dalam bisnis distribusi nasional. $X$ Ekpress adalah pengembangan usaha logistik dengan layanan terintegrasi yang akan didedikasikan kepada perusahaan yang mempercayai perusahaan logistik serta konsumen dari lapisan masyarakat dengan cepat dan efisien. Keputusan perusahaan untuk terjun ke bisnis kurir dilandasi semangat mengoptimalisasikan infrastruktur perusahaan yang memiliki 24 cabang dan 500 jaringan di Indonesia. Selain itu perusahaan mempunyai teknologi, sumber daya manusia, dan ratusan armada yang siap melayani. Perusahaan merasa yakin di dalam bisnis ini (kurir atau pengiriman cepat) tidak ada yang mendominasi, tidak ada market leader. Perkiraan perusahaan, pesaing yang bergerak pada bisnis ini hanya menguasai 15 sampai 17\% pasar.

\section{Rumusan Masalah}

Pertumbuhan industri logistik di Indonesia setiap tahunnya mengalami kenaikan dan tumbuh sangat cepat. Menurut data bisnis logistik di Indonesia tumbuh sekitar $15 \%$ sampai $20 \%$ per tahunnya, dengan total pasar transportasi dan logistik di Indonesia yang sekitar Rp 1.849 triliun. $^{3}$

X Ekspress merupakan bisnis unit yang diluncurkan oleh Perusahaan logistik BUMN untuk dapat bersaing dengan perusahaan industri logistik lainnya. Tetapi dalam pembentukan $\mathrm{X}$ Ekspress, perusahaan mendapatkan masalah dari bisnis tersebut. Perusahaan sudah cukup mengeluarkan investasi yang cukup besar pada X Ekspress. Akan tetapi banyak faktor lingkungan internal maupun eksternal yang mempengaruhi bisnis tersebut sehingga saat ini $\mathrm{X}$ Ekspress tidak memberikan keuntungan untuk perusahaan. Hal ini dapat dilihat pada tabel 1.1 laporan laba rugi untuk periode tahun 2015 dan 2016. Pada tabel dibawah untuk periode tahun 2015 perusahaan mengalami kerugian sebesar Rp -2.602.861.094,90 sedangkan untuk periode tahun 2016 kerugian semakin tinggi dengan selisih Rp -5.117.011.394,54 dari periode sebelumnya.

\footnotetext{
${ }^{3}$ Munady. 2015. Pertumbuhan Bisnis Logistik Sangat Cepat. Pikiran Rakyat. Bandung. http://www.pikiranrakyat.com/ekonomi/2015/05/29/329099/pertumbuhan-bisnis-logistik-sangat-cepat diakses 9 April 2017
} 
PRIMANOMICS : JURNAL EKONOMI DAN BISNIS - VOL. 17. NO. 2 (2019)

Versi Online Tersedia di : https://jurnal.ubd.ac.id/index.php/ds

| 1412-632X (Cetak) | 2614-6789 (Online) |

Tabel Laporan Laba Rugi X Ekspress Periode 2015 sampai 2016 (data sudah diolah)

\begin{tabular}{|l|c|c|}
\hline \multicolumn{1}{|c|}{ KETERANGAN } & 2015 & 2016 \\
\hline Pendapatan Express & $3,947,066,235.31$ & $11,188,681,844.51$ \\
\hline Jml. By. Operasi Express & $5,122,465,302.67$ & $15,450,409,594.91$ \\
\hline Laba Rugi Operasi & $\mathbf{- 1 , 1 7 5 , 3 9 9 , 0 6 7 . 3 6}$ & $\mathbf{- 4 , 2 6 1 , 7 2 7 , 7 5 0 . 4 0}$ \\
\hline Jumlah By. Usaha & $1,315,225,732.04$ & $3,173,004,343.17$ \\
\hline Laba Rugi Usaha & $\mathbf{- 2 , 4 9 0 , 6 2 4 , 7 9 9 . 4 0}$ & $\mathbf{- 7 , 4 3 4 , 7 3 2 , 0 9 3 . 5 7}$ \\
\hline Jumlah Beban Non & & \\
Usaha & $-112,093,145.50$ & $-284,997,245.87$ \\
\hline Laba (Rugi) Sebelum & & \\
Pajak & $\mathbf{- 2 , 6 0 2 , 7 1 7 , 9 4 4 . 9 0}$ & $\mathbf{- 7 , 7 1 9 , 7 2 9 , 3 3 9 . 4 4}$ \\
\hline Laba Setelah Pajak & $\mathbf{- 2 , 6 0 2 , 8 6 1 , 0 9 4 . 9 0}$ & $\mathbf{- 7 , 7 1 9 , 8 7 2 , 4 8 9 . 4 4}$ \\
\hline
\end{tabular}

Sumber: Perusahaan Logistik BUMN

Dalam menjalankan bisnisnya, X Ekspress relatif mendapatkan komplain dari konsumen. Selain itu, operasional di X Ekspress tidak berjalan dengan lancar sehingga banyak penyetopan agen yang dilakukan. Menurut David (2011) manajemen strategis terdiri dari lingkungan internal yang meliputi kekuatan dan kelemahan yang dimiliki oleh perusahaan serta lingkungan eksternal yang meliputi peluang dan ancaman bagi perusahaan. ${ }^{4}$ Dengan melihat permasalahan ini penulis ingin menganalisa penerapan strategi bersaing perusahaan logistik BUMN dalam industri logistik dengan melakukan analisa terhadap faktor internal dan ekternal perusahaan dan memberi usulan serta memformulasikan strategi bersaing yang tepat bagi perusahaan untuk memenangkan persaingan dalam industri logistik.

\section{Tujuan Penelitian}

1 Menganalisa strategi bersaing perusahaan logistik dalam industri logistik dengan melakukan analisa terhadap faktor internal dan ekternal perusahaan.

2 Memberi usulan dan memformulasikan strategi bersaing yang tepat bagi perusahaan untuk memenangkan persaingan dalam industri logistik.

\section{Lingkup Penelitian}

Penelitian ini dibatasi pada analisis lingkungan makro, five forces competition, SWOT, analisis lingkungan internal dan strategi bersaing perusahaan. Analisis lingkungan makro dan five forces competition bertujuan untuk mengkaji keadaan eksternal perusahaan. Analisis lingkungan internal meliputi analisis sumber daya, kapabilitas fungsional, dan kompetensi inti. Analisis SWOT merupakan cara sistematis untuk mengidentifikasi faktor kekuatan, kelemahan, peluang, dan ancaman serta strategi yang menggambarkan kesesuainnya dengan keempat faktor tersebut. Analisis strategi bersaing perusahaan bertujuan agar perusahaan memenangkan persaingan dalam industri logistik. Untuk merumuskan strategi bersaing perusahaan berdasarkan analisis SWOT, analisis struktural industri, serta

\footnotetext{
${ }^{4}$ David, F.R. 2011. Strategic Management: concepts and cases $\left(13^{\text {th }}\right.$ ed). New Jersey: Prentice Hall, Inc
} 
analisis lingkungan internal, dan lingkungan eksternal. Hasil analisis ini juga akan membantu perusahaan dalam melakukan tinjauan ulang mengenai strategi yang diterapkan.

\section{METODE PENELITIAN \\ Desain Penelitian}

Desain penelitian merupakan rencana dan struktur penyelidikan yang dibuat sedemikian rupa agar diperoleh jawaban atas pertanyaan-pertanyaan penelitian. Beberapa jenis desain penelitian yang dapat digunakan adalah penjajakan, deskriptif, dan kausal (Cooper \& Schindler, 2014). Desain penelitian yang digunakan pada penelitian ini menggunakan pendekatan kualitatif dengan metode deskriptif. Pendekatan kualitatif dipandang lebih relevan karena bertujuan menggali dan memahami kondisi faktor internal dan faktor eksternal perusahaan yang diharapkan dapat memberikan masukan kepada perusahaan mengenai strategi yang sudah diterapkan oleh perusahaan selama ini. Menurut Bogdan dan Taylor $(1975,5)$ berpendapat pendekatan kualitatif adalah prosedur penelitian yang menghasilkan data deskriptif berupa kata-kata tertulis atau lisan dari orang-orang dan perilaku yang dapat diamati.

\section{Metoda Pengumpulan Data}

Metoda pengumpulan data merupakan cara yang digunakan penulis untuk mendapatkan data dalam suatu penelitian. Sesuai dengan pendekatan penelitian yang akan dilakukan penulis, maka data yang akan digunakan adalah data kualitatif. Menurut Miles dan Huberman (1994) menjelaskan bahwa data kualitatif merupakan sumber dari deskripsi yang luas dan memuat penjelasan tentang proses-proses yang terjadi dalam lingkup setempat serta lebih condong dapat membimbing penulis untuk memperoleh penemuan-penemuan yang tidak diduga sebelumnya dan untuk membentuk kerangka teoritis baru, data tersebut membantu penulis untuk melangkah lebih jauh dari praduga dan kerangka kerja awal.

Sumber Data

Berdasarkan pendapat pakar di atas penulis menggunakan jenis data kualitatif dengan sumber data responden yang dibagi menjadi dua yaitu sumber primer yang didapatkan langsung dari objek penelitian dan sumber sekunder yang didapatkan secara tidak langsung berhubungan dengan obejek penelitian.

1. Sumber data primer.

Data primer merupakan sumber data yang diperoleh langsung dari sumber asli (tidak melalui media perantara). Data primer dapat berupa opini subjek (orang) secara individual atau kelompok, hasil observasi terhadap suatu benda (fisik), kejadian atau kegiatan, dan hasil pengujian. Adapun yang menjadi sumber data primer dalam penelitian ini yaitu Manager Pengembangan SDM, General Manager X Ekpress, General Manager Perencanaan, General Manager Pengembangan Usaha \& Umum, Staff Pengembangan Usaha \& Umum.

2. Data Sekunder

Data sekunder merupakan sumber data penelitian yang diperoleh peneliti secara tidak langsung melalui media perantara (diperoleh dan dicatat oleh pihak lain). Data sekunder umumnya berupa bukti, catatan atau laporan historis yang telah tersusun dalam arsip (data dokumenter) yang dipublikasikan dan yang tidak dipublikasikan. Pada penelitian ini penulis mengambil data yang diperoleh dari data internal perusahaan, Laporan keuangan perusahaan logistik BUMN, Laporan Keuangan X Ekspress, Laporan Tahunan perusahaan logistik BUMN, penelitian sebelumnya, jurnal, buku, dan internet.

Teknik Pengumpulan Data

Menurut Creswell (1994: 150-151) berdasarkan tipe data kualitatif maka terdapat 4 (empat) macam tipe pengumpulan data, yaitu observasi, wawancara, dokumen, dan alatalat audiovisual. Atas dasar hal tersebut penulis mengklasifikasikan teknik pengumpulan 
informasi (data) menjadi 3 (tiga) jenis, yaitu: observasi, wawancara, dan dokumen, sedangkan alat-alat audiovisual penulis sebut sebagai alat bantu pengumpulan data. Selain ketiga jenis teknik pengumpulan informasi (data) yang dilakukan, penulis juga menggunakan studi literature sebagai acuan dalam penelitian tersebut. Berikut uraian masing-masing teknik pengumpulan data yang dilakukan yaitu:

1. Observasi

Observasi hakikatnya merupakan kegiatan dengan menggunakan pancaindera, bisa penglihatan, penciuman, pendengaran, untuk memperoleh informasi yang diperlukan untuk menjawab masalah penelitian. Hasil observasi berupa aktivitas, kejadian, peristiwa, objek, kondisi atau suasana tertentu, dan perasaan emosi seseorang. Observasi dilakukan untuk memperoleh gambaran riil suatu peristiwa atau kejadian untuk menjawab pertanyaan penelitian (Guba dan Lincoln, 1981: 191-193). Menurut Cooper dan Schindler (2014) menyatakan observasi diklasifikasikan menjadi dua yaitu:

a. Non perilaku yang meliputi analisis catatan, analisis kondisi fisik, dan analisis proses atau aktivitas

b. Perilaku yang meliputi analisis non-verbal, analisis linguistik, analisis ekstralinguistik, dan analisis parsial

Dalam penelitian ini, penulis mengamati secara langsung obyek penelitian dan mendapatkan gambaran dari hasil pengamatan tersebut. Observasi yang dilakukan adalah melihat langsung karyawan saat bekerja.

2. Wawancara

Wawancara merupakan teknik pengumpulan data primer untuk mengumpulkan data dalam metodologi kualitatif. Menurut Cooper \& Schindler (2014) menyatakan wawancara memiliki variasi berdasarkan jumlah orang yang terlibat selama wawancara, tingkat strukutr, kedekatan antara pewawancara dengan peserta, dan jumlah wawancara yang dilakukan selama penelitian. Dalam melakukan wawancara terdapat dua jenis wawancara (Cooper \& Schindler, 2014) yaitu:

1. Wawancara mendalam (in-depth interview), di mana peneliti menggali informasi secara mendalam dengan cara terlibat langsung dengan kehidupan informan dan bertanya jawab secara bebas tanpa pedoman pertanyaan yang disiapkan sebelumnya sehingga suasananya hidup, dan dilakukan berkali-kali.

2. Wawancara terarah (guided interview) di mana peneliti menanyakan kepada informan hal-hal yang telah disiapkan sebelumnya. Berbeda dengan wawancara mendalam, wawancara terarah memiliki kelemahan, yakni suasana tidak hidup, karena peneliti terikat dengan pertanyaan yang telah disiapkan sebelumnya. Sering terjadi pewawancara atau peneliti lebih memperhatikan daftar pertanyaan yang diajukan daripada bertatap muka dengan informan, sehingga suasana terasa kaku.

Dalam penelitian ini, penulis menggunakan wawancara mendalam dengan pihakpihak yang berkaitan dengan penelitian ini yaitu Manager Pengembangan SDM, General Manager X Ekpress, General Manager Perencanaan, General Manager Pengembangan Usaha \& Umum, Staff Pengembangan Usaha \& Umum. Penulis memilih melakukan wawancara mendalam dengan tujuan untuk mengumpulkan informasi yang kompleks berdasarkan pendapat dan pengalaman pribadi dari masing-masing informan.

3. Dokumentasi

Dokumen berupa catatan-catatan pendukung dan audiotapes dari hasil wawancara akan membuat penelitian semakin sah dan dapat dipercaya. Dokumen yang digunakan oleh penulis dalam penelitian ini berupa foto, audiotapes, website mainpage, e-mails, dan 
data-data mengenai perusahaan logistik BUMN.

4. Studi Literatur

Studi literatur merupakan teknik pengumpulan data yang dilakukan dengan mempelajari buku, referensi, majalah, jurnal atau media lainnya yang berhubungan dengan objek penelitian. Tujuan studi literatur untuk memperoleh informasi yang berhubungan dengan teori dan konsep yang berkaitan dengan permasalahn penelitian yaitu analisa lingkungan makro,analisis lingkungan industri (Porter's Five Forces Analysis), analisis lingkungan internal, SWOT, dan strategi generik.

Waktu Pelaksanaan

Waktu pelaksanaan rangkaian wawancara awal dan mengumpulkan informasi data awal dari tempat penelitian yaitu Perusahaan logistik BUMN di Jakarta dilakukan mulai Februari 2017. Secara keseluruhan penelitian ini akan berlangsung dari bulan Februari sampai Mei 2017.

Informasi mengenai Informan

Peneilitian ini dimulai dengan penulis meminta izin kepada tempat penelitian untuk melakukan penelitian di perusahaan logistik BUMN. Penulis akan menjelaskan atau memberikan gambaran dan latar belakang secara ringkas dan jelas mengenai penelitian yang akan dilakukan. Selain itu untuk menghidari kehilangan informasi pada saat wawancara, penulis sebaiknya meminta izin kepada informan untuk menggunakan alat perekam pada saat wawancara.

Penulis akan melakukan wawancara mendalam dengan informan yang benar-benar memahami dan mengetahui situasi obyek penelitian. Informan yang digunakan oleh penulis yaitu Manager Pengembangan SDM, General Manager X Ekpress, General Manager Perencanaan, General Manager Pengembangan Usaha \& Umum, Staff Pengembangan Usaha \& Umum. Dengan pemilihan informan tersebut, penulis berharap mendapatkan informasi yang akurat mengenai situasi dan kondisi di perusahaan logistik BUMN. Informasi tersebut nantinya akan berkaitan dengan faktor lingkungan eksternal dan faktor lingkungan internal yang diharapkan penulis dapat mengetahui kekuatan, kelemahan, ancaman, dan peluang perusahaan logistik BUMN serta langkah startegi untuk meningkatkan pemasaran dan penjualan perusahaan.

Setelah melakukan wawancara, penulis akan melanjutkan dengan membuat transkip wawancara dengan memutar kembali rekaman hasil wawancara kemudian menuliskan katakata yang didengar sesuai dengan hasil rekaman tersebut. Hasil penulisan wawancara akan digunakan untuk mengambil dan mencatat informasi-informasi yang bermanfaat sesuai dengan konten penelitian serta mengabaikan kata-kata yang tidak perlu sehingga didapatkan inti kalimatnya saja, tetapi susunan bahasanya sesuai dengan bahasa informan. Berikut sumber yang akan diwawancarai atau informan dari penelitian ini adalah sebagai berikut: 
Tabel Daftar Informan

\begin{tabular}{|c|c|c|}
\hline Jabatan & Nama & Keterangan \\
\hline Manager Pengembangan & M. Alib & Informan 1 \\
\hline SDM & Sabarudin & \\
\hline General Manager X & Guswandri & Informan 2 \\
\hline \multicolumn{3}{|l|}{ Ekspress } \\
\hline General Manager & Farhan Isma & Informan 3 \\
\hline Perencanaan & Putra & \\
\hline General Manager & Tri Wahyundo & Informan 4 \\
\hline Pengembangan Usaha \& & & \\
\hline Umum & & \\
\hline Staff Pengembangan & Riza Purbo & Informan 5 \\
\hline Usaha \& Umum & Widiasto & \\
\hline
\end{tabular}

Sumber: Data Diolah oleh Penulis

\section{Metode Analisa Data}

Metode analisis data adalah hal yang terpenting dalam sebuah penelitian. Tanpa adanya analisis data, maka kesahihan sebuah penelitian masih diragukan. Karena dengan analisis datalah penelitian itu akan menghasilkan hasil penelitian yang akurat. Menentukan metode analisis data dalam sebuah penelitian adalah suatu hal yang wajib. Dan penentuannya berdasarkan jenis penelitian yang dilakukan (Miles dan Huberman, 1994).

Dalam penelitian ini analisis dilakukan menitikberatkan pada analisis strategi bersaing Perusahaan logistik BUMN di Jakarta. Analisis ini dilakukan untuk mengemukakan berbagai faktor yang mempengaruhi strategi bersaing perusahaan logistik BUMN dan untuk memperoleh gambaran yang menyeluruh berkaitan dengan keunggulan bersaing perusahaan tersebut.

\section{Analisis Faktor Eksternal}

Pada tahap ini dilakukan analisa mengenai faktor-faktor eksternal perusahaan logistik BUMN. Faktor-faktor eksternal yang dianalisa antara lain faktor ekonomi makro dan mikro, kebijakan pemerintah Indonesia terkait dengan kebijakan fiskal dan moneter, kebijakan pemerintah yang terkait dengan industri logistik, demografi, kondisi politik, teknologi, sosial budaya, dan lainnya. Tahap ini juga dilakukan analisa mengenai lingkungan industri logistik dengan menggunakan Porter 5 Forces Analysis.

\section{Analisis Faktor Internal}

Pada tahap ini dilakukan analisa mengenai faktor-faktor di internal perusahaan logistik yang bisa mempengaruhi dalam pencapaian tujuan perusahaan. Analisis lingkungan internal yang akan dilakukan akan meliputi analisis mengenai sumber daya manusia, kapabilitas, dan kompetensi inti yang dimiliki oleh perusahaan.

\section{Analisis SWOT}

Pada tahap ini, analisis SWOT dilakukan untuk mengidentifikasi berbagai faktor secara sistematis untuk merumuskan strategi perusahaan. Analisis ini meruapakan penggabungan hasil dari dua analisis sebelumnya yaitu analisis internal dan analisis eksternal. 
Dimensi faktor internal yaitu kekuatan dan kelemahan dan dimensi faktor eksternal adalah faktor peluang dan ancaman.

Dalam melakukan analisis ini, terlebih dahulu dilakukan identifikasi faktor-faktor yang menjadi kekuatan dan kelemahan termasuk dalam faktor internal perusahaan, serta faktor-faktor yang menajdi ancaman dan peluang bagi perusahaan yang termasuk dalam faktor eksternal perusahaan.

\section{Formulasi strategi dan rekomendasi}

Pada tahap ini dilakukan analisa mengenai kesesuaian antara strategi perusahaan saat ini dengan hasil analisa internal dan eksternal perusahaan. Pada tahap ini penulis memberikan usulan strategi alternatif apabila dalam analisa strategi perusahaan saat ini dirasa belum optimal untuk memenangkan persaingan di dalam industri.

\section{HASIL DAN PEMBAHASAN}

\section{Analisis SWOT}

Analisis SWOT adalah indentifikasi berbagai faktor secara sistematik untuk merumuskan strategi perusahaan. Analisis ini didasarkan pada kombinasi faktor eksternal dan internal perusahaan yang dapat mempengaruhi kinerja perusahaan. Evaluasi secara keseluruhan tentang kekuatan, kelemahan, peluang, dan ancaman perusahaan dilakukan dengan metode yang dikenal dengan analisis SWOT.

\section{Peluang}

- Potensi logistik di Indonesia memiliki potensi yang cukup besar yaitu jauh lebih besar dari US $\$ 33,34$ miliar dimana perkiraan ini didapatkan dari adanya kegiatan logistik yang tersembunyi, akibat adanya sektor-sektor industri yang melayani jasa angkutan dan distribusi sendiri.

- Berkembangnya bisnis e-commerce menjadi peluang untuk pelaku industri logistik untuk ekspansi atau membuat layanan terbaru.

- Perkembangan teknologi informasi dapat membuat pelaku industri logistik berkolaborasi dengan perusahaan lain untuk memberikan layanan lebih baik untuk konsumen.

- Indonesia memiliki posisi strategis di pasar logistik kawasan ASEAN karena jumlah penduduk dan volume perdagangan yang sangat besar.

- Indonesia dinilai sebagai Negara terbaik untuk investasi dalam satu sampai tiga tahun kedepan.

- Arah kebijakan pemerintahan baru dibawah kepemimpinan Presiden Joko Widodo sudah mengarah pada mempercepat pembangunan infrastruktur logistik.

- Kebijakan ekonomi jilid XV akan memberikan peluang untuk perusahaan nasional agar lebih berperan dalam sektor logistik serta memperkuat peran Indonesia National Single Window (INSW) dalam layanan kepabeanan.

\section{Ancaman}

- Secara Global sektor logistik Indonesia belum dapat bersaing dengan negara-negara yang lain dikarenakan biaya logistik di Indonesia masih tergolong mahal.

- Adanya ancaman untuk pendatang baru masuk ke industri logistik dengan adanya perkembangan $e$-commerce.

- Dengan adanya Masyarakat Ekonomi ASEAN yang sudah diterapkan pada tahun 2015 yang berarti tidak ada lagi batas dalam perdagangan komoditas dan jasa di negara-negara sekitar.

- Perusahaan jasa logistik ilegal yang memasuki pangsa pasar sekitar $60 \%$, akibatnya perusahaan jasa pengiriman dan logistik yang legal berkurang hingga $30 \%$ per tahun. 
- Dengan adanya regulasi Peraturan Menteri Keuangan Nomor 182/PMK.04/2016 untuk industri jasa pengiriman internasional mengalami ancaman karena regulasi tersebut membuat kedatangan barang yang diimpor memakan waktu yang lebih lama.

- Ancaman pendatang baru untuk memasuki industri logistik tinggi.

- Daya tawar konsumen dalam industri logistik tinggi.

- Daya tawar pemasok dalam industri logistik cukup kuat.

- Potensi pengembangan produk pengganti dalam industri logistik tergolong sedang.

- Persaingan antarperusahaan sejenis dalam industri logistik tergolong tinggi.

Dengan melihat pada analisis lingkungan internal perusahaan, Perusahaan logistik BUMN diharapkan mampu untuk mengantisipasi dan menghadapi baik peluang dan ancaman yang datang dari lingkungan eksternal perusahaan dengan mengetahui apa yang menajdi kekuatan dan kelemahan yang dimiliki oleh perusahaan.

\section{Kekuatan}

- Adanya program ODP untuk eksternal dan internal yang bertujuan untuk program pengembangan karir di Perusahaan logistik BUMN.

- Turn over di Perusahaan logistik BUMN kecil.

- Memiliki 1 kantor pusat dan 24 kantor cabang.

- Memiliki gudang milik sendiri yang berjumlah 151 unit, gudang sewa yang berjumlah 343 unit, dan gudang manajemen berjumlah 106 unit.

- Memiliki armada 295 unit yang tersebar diseluruh kantor cabang dan kantor pusat.

- Outlet X Ekspress berjumlah 333 outlet dan mobil untuk operasional berjumlah 35 mobil.

- Nama perusahaan yang sudah dikenal oleh masyarakat dengan lamanya perusahaan berdiri lebih dari 39 tahun.

- Loyalitas konsumen terhadap perusahaan.

- Portofolio konsumen setiap tahunnya meningkat.

- Selalu cepat tanggap mengenai komplain dari konsumen.

- Setiap usaha Perusahaan logistik BUMN mengalami peningkatan setiap tahunnya dilihat dari pendapatan 2016

- Semua usaha Perusahaan losgistik BUMN sudah menggunakan sistem TI dan sudah terintegrasi.

- Perusahaan logistik BUMN memiliki layanan yang unggul yaitu ILS untuk mencari solusi yang tepat untuk konsumen.

- Memiliki gudang yang strategis.

- Memiliki gudang yang tertutup dan terbuka sesuai dengan kebutuhan konsumen.

- Gudang Perusahaan logistik BUMN sudah sesuai dengan ISO dan sudah tersertifikasi.

\section{Kelemahan}

- HR sering kali tidak menggunakan prosedur yang ada untuk merekrut karyawan baru.

- Untuk menjadi karyawan tetap di Perusahaan logistik BUMN relatif sulit.

- Tidak terdapat KPI untuk masing-masing departemen.

- Beberapa outlet X Ekspress sudah tutup.

- Kantor pusat hanya sebagai supporting semua pemasaran dilakukan di kantor cabang.

- Harga untuk konsumen kantor cabang yang mengendalikan.

- Tidak maksimalnya pemasaran untuk X Ekspress.

- Untuk layanan X Ekspress belum dilakukan survey kepuasan konsumen.

- Dilihat dari laba untuk X Ekspress mengalami kerugian yang cukup besar. 
- Perlunya pengembangan terhadap website $\mathrm{X}$ Ekspress dengan menyediakan layanan tracking.

- Belum optimalnya struktur organisasi Perusahaan logistik BUMN.

\section{Analisis Strategi Bersaing}

Pada analisis strategi bersaing perusahaan dilakukan berdasarkan analisis lingkungan eksternal, analisis lingkungan internal, dan analisis SWOT. Analisis strategi bersaing perusahaan akan menjadi dasar dalam membuat formulasi strategi perusahaan. Keunggulan bersaing menggambarkan cara perusahaan memilih dan mengimplementasikan strategi generik untuk mencapai dan mempertahankan keunggulan bersaing (Porter,1989). Pada analisis ini penulis akan menjelaskan strategi generik yang dapat membantu Perusahaan logistik BUMN memperoleh keunggulan kompetitif, yaitu keunggulan biaya, diferensiasi, dan fokus.

\section{Strategi Keunggulan Biaya}

Perusahaan yang mempunyai posisi biaya rendah menghasilkan keuntungan diatas rata-rata perusahaan lainnya dalam industri, karena perusahaan dapat menjual produknya pada harga rata-rata perusahaan dalam industri untuk mendapatkan keuntungan lebih tinggi dari pesaingnya atau perusahaan dapat menjual produknya dibawah harga rata-rata yang ada untuk mendapatkan pangsa pasar yang lebih besar. Saat terjadi perang harga perusahaan yang berbiaya rendah masih mendapatkan keuntungan, sementara para pesaing menderita kerugian. Saat industri berada pada siklus maturity dan harga produk cenderung mengalami penurunan, perusahaan yang berbiaya rendah akan lebih mampu memproduksi lebih murah dan tetap masih mendapatkan keuntungan jangka panjang. Strategi ini biasanya menargetkan pada pangsa pasar yang lebih luas. Perusahaan yang sukses dalam kepemimpinan biaya sering mempunyai kekuatan internal sebagai berikut:

1. Saluran distribusi yang efisien.

2. Pengalaman tingkat tinggi dalam memasarkan produk jasa.

3. Akses pada modal yang dibutuhkan dan membuat investasi yang signifikan dalam akses distribusi dan operasional, sehingga investasi ini merepresentasikan hambatan masuk bagi banyak perusahaan yang tidak memiliki kemampuan untuk masuk.

Resiko yang dihadapi oleh perusahaan dengan strategi ini adalah adanya kemungkinan pesaing akan melakukan yang sama,yakni melakukan penurunan biaya dan adanya ancaman dari teknologi yang berkembang dengan pesat, sehingga memberikan kesempatan pada para pemain untuk melakukan ekpansi bisnis.

Meskipun Perusahaan logistik BUMN memiliki 24 kantor cabang dan asset yang mendukung untuk menjalankan bisnis. Untuk beberapa layanan atau produk yang ditawarkan oleh perusahaan sudah didistibusi secara baik tetapi untuk layanan terbaru perusahaan yaitu $\mathrm{X}$ Ekspress perusahaan belum optimal melakukan pemasaran. Sehingga modal dan investasi yang dilakukan untuk layanan terbaru belum mencapai keunggulan biaya. Pada dasarnya layanan X Ekspress hampir sama cara pemasaran dengan produk jasa exsiting Perusahaan logistik BUMN tetapi untuk target pasar berbeda dengan yang lain. Untuk dapat menerapkan strategi ini, maka perusahaan perlu melakukan pembenahan pada beberapa proses bisnis yang saat ini ada, yaitu:

1. Mengevaluasi layanan X Ekspress apakah perlu dilanjutkan atau divestasi.

2. Mencari cara untuk mengurangi biaya yang tidak perlu yang terjadi pada proses bisnis yang ada saat ini, dengan menjadikan pembelajaran dan pengalaman.

3. Memanfaatkan kerjasama yang dilakukan dengan perusahaan BUMN lainnya.

4. Memanfaatkan teknologi yang ada dan selalu mengikuti perkembangan TI. 


\section{Strategi Diferensiasi}

Strategi diferensiasi adalah kemampuan mengembangkan produk yang menawarkan atribut yang unik yang bernilai bagi konsumen dan konsumen menganggap produk tersebut lebih baik atau berbeda dengan produk yang ditawarkan oleh pesaing. Nilai tambah melalui keunikan produk memungkinkan perusahaan menetapkan harga yang lebih tinggi. Sehingga dengan harga yang tinggi itu perusahaan akan dapat menutupi biaya operasional. Perusahaan sukses dalam strategi diferensiasi sering mempunyai kekuatan internal yaitu akses pada riset terdepan, tim pemasaran yang kuat, reputasi perusahaan, keahlian dan tim pengembangan produk yang memiliki kreatifitas yang tinggi. Resiko yang dihadapi perusahaan dengan strategi diferensiasi adalah adanya inovasi produk yang ditawarkan tidak mendapatkan respon yang baik dari konsumen dan terjadinya perubahan tren yang membuat selera konsumen menjadi berubah.

Saat ini Perusahaan logistik BUMN sudah menerapkan strategi diferensiasi, hal ini terlihat dengan layanan yang ditawakan oleh perusahaan. Layanan utama perusahaan adalah logistik dengan membuat layanan pendukung yaitu pergudangan serta transportasi. Dengan memiliki armada yang cukup banyak, perusahaan membuka layanan terbaru yaitu $X$ Ekspress. Layanan tersebut merupakan inovasi perusahaan dalam bisnis kurir. Perusahaan mendirikan layanan kurir, karena melihat asset yang dimiliki oleh perusahaan. Dengan mendirikan X Ekspress sama saja dengan layanan yang lain tetapi perusahaan melihat layanan kurir yang belum dimiliki dapat menjadi inovasi produk yang ditawarkan oleh perusahaan. Selain itu reputasi perusahaan dalam industri logistik sudah sangat dikenal oleh masyarakat sehingga perusahaan tidak merasakan kesulitan pada saat launching layanan $\mathrm{X}$ Ekspress. Namun dalam 2 tahun berdirinya X Ekspress banyak yang perlu dibenahi. Kemampuan tim pemasaran dalam setiap layanan yang sudah ada belum optimal karena dasarnya pendekatan yang dilakukan oleh manajemen perusahaan langsung ke kementrian dan direksi. Tetapi tim pemasaran sangat bertanggung jawab terhadap komplain yang terima oleh konsumen dan setiap tahunnya tim pemasaran melakukan survey kepuasan pelanggan. Untuk portofolio pelanggan memang meningkat setiap tahunnya, karena adanya pemasaran kepada korporat yang potensial untuk perusahaan. Selain itu banyak juga konsumen yang memiliki kontrak yang panjang dengan perusahaan karena merasakan layanan yang diberikan oleh perusahaan sangat baik.

\section{Strategi Fokus}

Strategi fokus berkonsentrasi pada segmen yang sempit, dan dalam segmen tersebut perusahaan berupaya untuk mencapai keunggulan biaya atau diferensiasi. Suatu grup target pasar tertentu dapat dilayani lebih baik melalui fokus pada pelanggan dan kebutuhannya. Perusahaan yang menggunakan strategi fokus menikmati derajat loyalitas yang tinggi dan loyalitas tersebut dapat sebagai penghambat atau penghalang bagi pesaing untuk berkompetisi secara langsung. Perusahaan yang melakukan strategi fokus biasanya mempunyai volume yang rendah karena fokus pasar yang sempit, oleh sebab itu daya tawar perusahaan sangat rendah terhadap pemasok. Perusahaan yang berusaha untuk fokus pada strategi diferensiasi akan mampu menghadapi biaya yang lebih tinggi melalui penetapan harga yang lebih tinggi kepada konsumen, karena minimnya produk pengganti. Perusahaan yang sukses didalam strategi fokus akan mampu menciptakan rangkaian pengembangan kekuatan produk pada segmen sempit yang mereka ketahui dengan baik.

Resiko yang dihadapi oleh perusahaan dengan strategi fokus adalah adanya kemungkinan perusahaan dengan kepemimpinan biaya dengan pasar yang lebih luas masuk ke segmen tersebut untuk menciptakan produk yang berkompetisi secara luas. Sedangkan perusahaan yang berusaha melakukan diferensiasi dalam menyediakan produk dengan 
memberikan kualitas yang baik, tidak akan mampu menjadi perusahaan yang mempunyai keungulan biaya dalam waktu yang bersamaan.

Menurut Porter (1989) menyarankan untuk kesuksesan jangka panjang perusahaan harus memilih hanya satu dari tiga strategi generik tersebut. Perusahaan yang mampu dan sukses dalam menerapkan beberapa pilihan strategi adalah perusahaan yang menciptakan unit bisnis yang berbeda-beda, tergantung dengan strategi yang diterapkan, sehingga unit yang berbeda akan mempunyai kebijakan serta budaya yang berbeda.

Saat ini Perusahaan logistik BUMN menerapkan juga strategi fokus pada diferensiasi, hal ini terlihat dari hampir 50\% market Perusahaan logistik BUMN adalah komoditas pupuk subsidi. Perusahaan logistik BUMN merupakan perusahaan BUMN yang bertanggung jawab untuk mendistribusikan pupuk subsidi ke konsumen. Perusahaan memiliki gudang yang cukup strategis dan armada yang memadai yang tersebar di seluruh Indonesia. Oleh karena itu industri pupuk subsidi untuk saat ini masih banyak menggunakan jasa Perusahaan logistik BUMN. Tabel 4.7 menjelaskan daftar 5 pelanggan terbesar yang dimiliki oleh Perusahaan logistik BUMN dalam mendistribusikan pupuk subsidi ke konsumen.

Tabel Daftar 5 Pelanggan Terbesar Perusahaan logistik BUMN

\begin{tabular}{|c|l|c|c|}
\hline \multirow{2}{*}{ NO } & \multicolumn{1}{|c|}{ PERUSAHAAN / PELANGGAN } & $\begin{array}{c}\text { KONTRIBUSI } \\
\text { PENDAPATAN S/D BULAN } \\
\text { Feb 2017 }\end{array}$ & $\%$ \\
\hline 1 & PETROKIMIA GRESIK, PT & $38,215,614,283.00$ & 26,37 \\
\hline 2 & PUPUK KALIMANTAN TIMUR, PT & $24,137,466,352.00$ & 16,66 \\
\hline 3 & WIJAYA KARYA BETON, PT & $7,330,196,967.00$ & 5,06 \\
\hline 4 & SEMEN JAYA, PT & $4,522,584,266.00$ & 3,12 \\
\hline 5 & PUPUK SRIWIDJAYA, PT & $3,926,909,638.00$ & 2,71 \\
\hline & SUB TOTAL & $\mathbf{7 8 , 1 3 2 , 7 7 1 , 5 0 6 . 0 0}$ & $\mathbf{5 3 , 9 2}$ \\
\hline & 515 Perusahaan lainnya & $66,769,338,018.00$ & 46,08 \\
\hline & $\begin{array}{l}\text { TOTAL PENDAPATAN + JASA KURIR } \\
\text { S/D BULAN Feb 2017 }\end{array}$ & $\mathbf{1 4 4 , 9 0 2 , 1 0 9 , 5 2 4 . 0 0}$ & $\mathbf{1 0 0}$ \\
\hline
\end{tabular}

Sumber: Data internal Perusahaan logistik BUMN

Namun seiring dengan waktu perusahaan tidak dapat hanya memfokuskan bisnis pada distribusi pupuk, oleh karena itu perusahaan mengembangkan layanan dengan membuat layanan ILS (Integrated Logistic Solution) dengan layanan ini tidak hanya industri pupuk saja yang dapat menggunakan layanan tersebut tetapi indusri lain yang memerlukan logistik dan sulit untuk mendistribusikan produk tersebut perusahaan dapat memberikan solusi yang tepat.

Selain layanan ILS, Perusahaan logistik BUMN juga membuat layanan pergudangan dan transportasi. Untuk layanan pergudangan perusahaan memberikan layanan untuk konsumen menyimpan produk di gudang perusahaan. Perusahaan memiliki 2 tipe gudang yaitu gudang terbuka dan gudang tertutup semua gudang milik sendiri maupun gudang yang disewa oleh Perusahaan logistik BUMN sudah tersertifikasi dan menggunakan sistem TI sehingga produk yang disimpan digudang Perusahaan logistik BUMN terjamin keamanannya. Sedangkan untuk layanan transportasi, perusahaan logistik BUMN memiliki layanan darat, laut, dan udara untuk menunjang layanan logistik perusahaan.

Layanan terbaru Perusahaan logistik BUMN yaitu layanan di bidang kurir, layanan ini didirikan dengan memanfaatkan armada yang dimiliki perusahaan. Namun pada layanan ini perlu dilakukan evaluasi lebih lanjut karena sampai saat ini layanan tersebut banyak memberikan kerugian untuk perusahaan.

\section{Rekomendasi Strategi}

Berdasarkan analisis strategi generik yang telah dilakukan, maka untuk Perusahaan logistik BUMN yang bermain di industri logistik sebaiknya fokus dengan strategi fokus pada diferensiasi. Dapat dilihat pada Tabel 4.8 merupakan daftar kontribusi pelanggan berdasarkan 
komoditas. Pada tabel tersebut komoditas pupuk sangat menunjang bisnis Perusahaan logistik BUMN, selain itu komoditas lainnya memberikan cukup kontribusi untuk bisnis Perusahaan logistik BUMN.

Tabel Daftar Kontribusi Pelanggan Pareto Berdasarkan Komoditas

\begin{tabular}{|c|c|c|c|c|}
\hline NO & NAMA PERUSAHAAN/ PELANGGAN & KOMODITAS & $\begin{array}{l}\text { KONTRIBUSI S/D } \\
\text { BULAN FEB } 2017 \\
\end{array}$ & $\%$ \\
\hline I & & STRATEGIS & & \\
\hline 1 & PETROKIMIA GRESIK, PT & PUPUK & $38,215,014,283.00$ & 26,37 \\
\hline 2 & PUPUK KALIMANTAN TIMUR, PT & PUPUK & $24,137,466,352.00$ & 16,66 \\
\hline 3 & PUPUK SRIWIDJAYA, PT & PUPUK & $3,926,909,638.00$ & 2,71 \\
\hline 4 & PUPUK ISKANDA MUDA, PT & \begin{tabular}{|c|} 
PUPUK \\
\end{tabular} & $2,682,225,777.00$ & 1,85 \\
\hline 5 & BADAN NASIONAL PB & \$ANTUAN KEBUTUHAN POKOI & $2,469,767,733.00$ & 1,7 \\
\hline 6 & WILMAR, PT & \begin{tabular}{|c|} 
CPO \\
\end{tabular} & $1,656,289,892.00$ & 1,14 \\
\hline 7 & PUPUK KUJANG, PT & PUPUK & $1,414,794,021.00$ & 0,98 \\
\hline 8 & SENTANA ADIDAYA PRATAMA, PT & PUPUK & $1,119,171,779.00$ & 0,77 \\
\hline 9 & MEROKE TETAP JAYA, PT & PUPUK & $990,998,746.00$ & 0,68 \\
\hline 10 & FOCUS DISTRIBUSI NUSANTARA, PT & CONSUMER GOODS & $979,825,230.00$ & 0,68 \\
\hline 11 & PERSON & PUPUK & $704,889,000.00$ & 0,49 \\
\hline 12 & UNILVER INDONESIA TBK, PT & CONSUMER GOODS & $691,320,000.00$ & 0,48 \\
\hline 13 & KHARISMA PEMASARAN BERSAMA, PT & PERKEBUNAN & $674,770,482.00$ & 0,47 \\
\hline \multirow[t]{2}{*}{14} & GARUDA FOOD, PT & CONSUMER GOODS & $670,736,877.00$ & 0,46 \\
\hline & SUB TOTAL & & $80,334,779,810.00$ & 55,44 \\
\hline II & & BERNILAI TINGGI & & \\
\hline 1 & SYNNEX METRODATA INDONESIA, PT & ELEKTRONIK KOMPUTER & $3,431,882,113.00$ & 2,37 \\
\hline 2 & WILMAR CHEMICAL INDONESIA, PT & BAHAN KIMIA & $3,374,789,477.00$ & 2,33 \\
\hline 3 & TIMAH (Persero) Tbk & TIMAH & $1,678,319,697.00$ & 1,16 \\
\hline 4 & ZTE INDONESIA, PT & ALAT KOMUNIKASI & $1,601,396,651.00$ & 1,11 \\
\hline 5 & ANUGERAH FHARMINDO LESTARI, PT & ALAT KESEHATAN & $1,117,277,000.00$ & 0,77 \\
\hline 6 & AVNET DATAMATION, PT & PRODUK IT & $709,988,275.00$ & 0,49 \\
\hline \multirow[t]{2}{*}{7} & TD ENERGY SERVICES, PT & KARGO KONTAINER & $635,200,000.00$ & 0,44 \\
\hline & $\begin{array}{c}\text { SUB TOTAL } \\
\end{array}$ & & $12,548,853,213.00$ & 8,66 \\
\hline III & & PROYEK & & \\
\hline 1 & WIJAYA KARYA BETON, PT & KONSTRUKSI & $7,330,196,967.00$ & 5,06 \\
\hline 2 & SEMEN JAYA, PT & SEMEN & $4,522,584,266.00$ & 3,12 \\
\hline 3 & KHI PIPE INDUSTRIES, PT & KONSTRUKSI PIPA & $2,493,982,912.00$ & 1,72 \\
\hline 4 & SEMEN BATURAJA, PT & SEMEN & $1,378,146,000.00$ & 0,95 \\
\hline 5 & JUI SHIN INDONESIA, PT & SEMEN & $1,075,446,656.00$ & 0,74 \\
\hline \multirow[t]{2}{*}{6} & WASKITA BETON PRECAST, PT & KONSTRUKSI & $867,250,000.00$ & 0,6 \\
\hline & $\begin{array}{l}\text { SUB TOTAL } \\
\end{array}$ & & $17,667,606,801.00$ & 12,19 \\
\hline IV & & NON KOMODITAS & & \\
\hline 1 & JASA KURIR & KURIR & $2,304,649,969.00$ & 1,59 \\
\hline 2 & HAKERSEN UTAMA, PT & \$A PENGIRIMAN VIA KERETA A & $1,546,180,169.00$ & 1,07 \\
\hline 3 & MASAJI TATANAN CONTAINER, PT & ASA PENGIRIMAN CONTAINEH & $742,781,700.00$ & 0,51 \\
\hline \multirow[t]{3}{*}{4} & OOCL INDONESIA, PT & ASA PENGIRIMAN CONTAINEH & $736,155,000.00$ & 0,51 \\
\hline & SUB TOTAL & & $5,329,766,837.65$ & 3,68 \\
\hline & JUMLAH I S/D IV & & $115,881,006,661.65$ & 79,97 \\
\hline
\end{tabular}

Sumber: Data Internal Perusahaan logistik BUMN

Alasan lain mengapa strategi fokus pada diferensiasi yang direkomendasikan adalah:

1. Perusahaan logistik BUMN

2. dalam mengembangkan bisnis telah melihat peluang bisnis yang ada dengan menentukan target pasar yang lebis spesifik, menetapkan geografis untuk beroperasi. Dengan menerapkan strategi fokus, perusahaan akan terhindar dari persaingan secara frontal dengan pemain yang sudah ada di pasar saat ini dan juga perusahaan akan dapat menikmati keuntungan diatas rata-rata industri. 
3. Dengan menggunakan strategi fokus pada diferensiasi, perusahaan akan mendapatkan keunggulan kompetitif di industri logistik yang tidak dimiliki oleh pemain lainnya. Dengan memiliki keunggulan kompetitif, perusahaan dapat merebut pasar tertentu, terutama segmen pasar yang minim dengan layanan tersebut.

4. Konsistensi visi dan misi yang dimiliki oleh Perusahaan logistik BUMN sudah sesuai dengan bisnis yang dikembangkan oleh perusahaan. Hal ini akan berdampak baik bagi kelangsungan hidup perusahaan di masa mendatang.

5. Kantor cabang, gudang, dan armada perusahaan yang tersebar hampir di seluruh kota besar Indonesia merupakan sebuah kekuatan perusahaan dalam menjalankan bisnis. Oleh karena itu sebaiknya asset yang ada dapat dikelola secara baik agar dapat menjadi keunggulan kompetitif unik yang tidak dimiliki oleh pesaing.

6. Pengalaman dan reputasi perusahaan yang sudah baik dapat dimanfaatkan oleh perusahaan untuk semakin menajamkan strategi yang dijalankan.

\section{KESIMPULAN}

Berdasarkan hasil kajian tentang analisis strategi bersaing perusahaan bergerak dibidang logistik di Jakarta dan pembahasan yang telah diuraikan, maka dapat diambil simpulan sebagai berikut :

1. Hasil analisis lingkungan ekternal berdasarkan lingkungan makro. Lingkungan makro yang dianalisis yaitu analisis faktor ekonomi, teknologi, hukum, dan regulasi. Dari hasil analisis faktor ekonomi potensi logistik di Indonesia memiliki potensi yang cukup besar yaitu jauh lebih besar dari US $\$ 33,34$ miliar dimana perkiraan ini didapatkan dari adanya kegiatan logistik yang tersembunyi, akibat adanya sektor-sektor industri yang melayani jasa angkutan dan distribusi sendiri. Namun, secara global sektor logistik Indonesia belum dapat bersaing dengan negara-negara lainnya yang dikarenakan biaya logistik di Indonesia tergolong mahal. Dari hasil analisis faktor teknologi, perkembangan $e$ commerce di Indonesia yang begitu pesat, berimbas pada pertumbuhan jasa logistik dan express. Pada periode 2016 sampai 2017 hampir semua penyedia jasa logistik dan express tumbuh diatas 30 persen. Berkembangnya bisnis e-commerce menjadi peluang untuk pelaku industri logistik untuk ekspansi atau membuat layanan terbaru. Perkembangan teknologi informasi dapat membuat pelaku industri logistik berkolaborasi dengan perusahaan lain untuk memberikan layanan lebih baik untuk konsumen. Namun, dengan perkembangan e-commerce banyak dimanfaatkan masuknya pesaing baru di indutri logistik. Dari analisis faktor hukum dan regulasi, Indonesia memiliki posisi strategis di pasar logistik kawasan ASEAN karena jumlah penduduk dan volume perdagangan yang sangat besar, Indonesia dinilai sebagai Negara terbaik untuk investasi dalam satu sampai tiga tahun kedepan. Arah kebijakan pemerintahan baru dibawah kepemimpinan Presiden Joko Widodo sudah mengarah pada mempercepat pembangunan infrastruktur logistik. Kebijakan ekonomi jilid XV akan memberikan peluang untuk perusahaan nasional agar lebih berperan dalam sektor logistik serta memperkuat peran Indonesia National Single Window (INSW) dalam layanan kepabeanan. Namun, dengan adanya Masyarakat Ekonomi ASEAN yang sudah diterapkan pada tahun 2015 yang berarti tidak ada lagi batas dalam perdagangan komoditas dan jasa di negara-negara sekitar. Perusahaan jasa logistik ilegal yang memasuki pangsa pasar sekitar 60\%, akibatnya perusahaan jasa pengiriman dan logistik yang legal berkurang hingga $30 \%$ per tahun. Dengan adanya regulasi Peraturan Menteri Keuangan Nomor 182/PMK.04/2016 untuk industri jasa pengiriman internasional mengalami ancaman karena regulasi tersebut membuat kedatangan barang yang diimpor memakan waktu yang lebih lama. Dampak yang terjadi konsumen menjadi tidak percaya lagi dengan perusahaan atau pabrik yang menyediakan 
barang tersebut. Sedangkan analisis berdasarkan Porter's Five Forces Model menunjukkan ancaman pendatang baru dari segi skala ekonomi tinggi, merk rendah, differensiasi produk tinggi, dan kebijakan pemerintah tinggi; daya tawar konsumen tinggi; daya tawar pemasok cukup kuat; potensi pengembangan produk pengganti sedang; persaingan antarperusahaan sejenis dari segi tingkat pertumbuhan industri tinggi dan jumlah pemain dalam industri tinggi.

2. Hasil analisis lingkungan internal berdasarkan sumber daya menunjukkan perusahaan peduli dengan pengembangan karir karyawan sehingga perusahaan membuat program ODP untuk eksternal dan internal perusahaan. Selain itu, turn over di Perusahaan logistik BUMN rendah karena loyalitas karyawan terhadap perusahaan sangat tinggi. Namun, dalam proses merekrut karyawan baru, HR sering kali tidak menggunakan prosedur yang ada karena sering kali permintaan kebutuhan karyawan baru datang pada saat adanya project besar. Untuk menjadi karyawan tetap di Perusahaan logistik BUMN relatif sulit, biasanya karyawan baru dikenakan kontrak setahun atau tiga tahun. Tidak terdapat KPI untuk masing-masing departemen sehingga sistem pemberian bonus sama rata disetiap departemen di cabang maupun di pusat. Asset fisik Perusahaan logistik BUMN yaitu memiliki 1 kantor pusat dan 24 kantor cabang di seluruh Indonesia. Selain itu, Perusahaan logistik BUMN memiliki gudang milik sendiri yang berjumlah 151 unit, gudang sewa berjumlah 343 unit, dan gudang manajemen berjumlah 106 unti. Sedangkan untuk armada Perusahaan logistik BUMN memiliki 295 armada yang tersebar di kantor pusat dan kantor cabang. Perusahaan logistik BUMN juga memiliki outlet X Ekspress berjumlah 333 outlet dan mobil untuk opersional berjumlah 35 mobil yang terdiri dari 28 mobil merk Daihatsu Grand Max dan 7 mobil truck box engkel. Tetapi untuk outlet X ekspress sekarang banyak yang sudah tutup dan mobil yang digunakan untuk operasional sudah berkurang. Asset yang tidak tampak yang dimiliki oleh Perusahaan logistik BUMN adalah nama besar perusahaan yang sudah dikenal oleh masyarakat dengan lamanya perusahaan berdiri lebih dari 39 tahun dan konsumen yang loyalitas terhadap perusahaan. Berdasarkan kapabilitas fungsional dari aspek pemasaran portofolio konsumen setiap tahunnya meningkat, team selalu cepat tanggap mengenai komplain dari konsumen. Namun, untuk pemasaran dilakukan diseluruh kantor cabang, kantor pusat hanya sebagai supporting dan harga untuk konsumen kantor cabang yang mengendalikan sehingga harga untuk setiap daerah berbeda. Selain itu, tidak maksimalnya pemasaran untuk X Ekspres karena dari awal target pemasaran untuk layanan tersebut sudah tidak tepat, seharusnya layanan tersebut sasaran target yaitu kalangan menengah kebawah tetapi team pemasaran melakukan pemasaran yang sama seperti layanan yang lain yaitu pemasaran ke perusahaan-perusahaan sehingga banyak masyarakat yang tidak mengetahui layanan terbaru dari Perusahaan logistik BUMN. Dan juga untuk layanan X Ekspress belum dilakukan survey kepuasan konsumen, hal ini merupakan point yang penting untuk perusahaan mengevaluasi layanan yang sudah ada. Aspek keuangan, tahun 2016 dari unit usaha pergudangan kontribusi terbesar berasal dari pos pergudangan sewa yang tercatat sebesar RP 209,94 miliar atau menyumbang 450,47 persen dari total pendapatan pergudangan. Dari bidang logistik, kontribusi terbesar berasal dari jasa kurir dengan nominal realisasi sebesar 11,19 miliar atau 63,16 persen dari keseluruhan pendapatan. Tetapi untuk bidang usaha kurir dari segi laba mengalami kerugian, data tersebut dapat dilihat pada Tabel 1.1. Aspek operasional, semua usaha Perusahaan logistik BUMN sudah menggunakan TI dan sudah terintegrasi. Namun, perlu pengembangan terhadap website $\mathrm{X}$ Ekspress dengan menyediakan layanan tracking. Aspek manajemen, struktur organisasi yang ada di Perusahaan logistik BUMN cenderung mempunyai tipe organisasi lini dan 
staff sehinggan merupakan suatu kekuatan bagi Perusahaan logistik BUMN karena dengan demikian akan mempunyai kewenangan atau otoritas operasional yang lebih besar dalam melaksanakan strategi bisnis. Namun dengan manajemen menggunakan tipe tersebut, struktur organisasi sampai saat ini belum berjalan dengan semestinya. Pimpinan maupun karyawan bekerja tidak sesuai dengan SOP yang telah ada. Sehingga struktur organisasi yang ada di Perusahaan logistik BUMN belum dilakukan secara optimal. Berdasarkan kompetensi inti yang dimiliki Perusahaan logistik BUMN yaitu berada pada distribusi dan pergudangan. Pada distribusi, Perusahaan logistik BUMN memberikan layanan unggulan Integrated Logistics Service (ILS), layanan ini biasanya digunakan oleh konsumen yang bergerak dalam industri pupuk sehingga banyak konsumen yang menggunakan Perusahaan logistik BUMN dalam mendistribusikan pupuk tersebut ke pengguna terakhir. Pada pergudangan, Perusahaan logistik BUMN memberikan layan kepada konsumen untuk menyewa gudang dan mengelola barang yang disimpan di gudang tersebut. Pergudangan ini sudah didukung dengan teknologi informasi, sistem keamanan yang handal serta sarana pendukung lainnya. Selain itu, gudang yang dimiliki oleh Perusahaan logistik BUMN tergolong strategis di setiap daerah sehingga peluang konsumen untuk menggunakan jasa atau layanan ini cukup besar.

3. Rekomendasi strategi yang tepat untuk Perusahaan logistik BUMN yaitu menggunakan strategi fokus pada diferensiasi. Hampir 50\% market Perusahaan logistik BUMN adalah komoditas pupuk subsidi, penjelasan tersebut dapat dilihat pada Tabel 4.8 yang merupakan daftar kontribusi pelanggan berdasarkan komoditas. Perusahaan logistik BUMN dalam mengembangkan bisnis telah melihat peluang bisnis yang ada dengan menentukan target pasar yang lebis spesifik, menetapkan geografis untuk beroperasi. Dengan menerapkan strategi fokus, perusahaan akan terhindar dari persaingan secara frontal dengan pemain yang sudah ada di pasar saat ini dan juga perusahaan akan dapat menikmati keuntungan diatas rata-rata industri. Dengan menggunakan strategi fokus pada diferensiasi, perusahaan akan mendapatkan keunggulan kompetitif di industri logistik yang tidak dimiliki oleh pemain lainnya. Dengan memiliki keunggulan kompetitif, perusahaan dapat merebut pasar tertentu, terutama segmen pasar yang minim dengan layanan tersebut. Konsistensi visi dan misi yang dimiliki oleh Perusahaan logistik BUMN sudah sesuai dengan bisnis yang dikembangkan oleh perusahaan. Hal ini akan berdampak baik bagi kelangsungan hidup perusahaan di masa mendatang. Kantor cabang, gudang, dan armada perusahaan yang tersebar hampir di seluruh kota besar Indonesia merupakan sebuah kekuatan perusahaan dalam menjalankan bisnis. Oleh karena itu sebaiknya asset yang ada dapat dikelola secara baik agar dapat menjadi keunggulan kompetitif unik yang tidak dimiliki oleh pesaing. Pengalaman dan reputasi perusahaan yang sudah baik dapat dimanfaatkan oleh perusahaan untuk semakin menajamkan strategi yang dijalankan.

\section{Implikasi Praktis}

Penelitian ini diharapkan mampu memberikan dampak positif untuk Perusahaan logistik BUMN dalam hal menciptakan keunggulan bersaing dalam bisnis logistik dengan melihat analisis lingkungan eksternal maupun lingkungan internal yang dimiliki oleh perusahaan. Analisis ini dilakukan untuk bertujuan agar perusahaan dapat terus tumbuh dan berkembang di tengah kondisi bisnis logistik yang terus menerus meningkat.

Perusahaan logistik BUMN diharapkan mampu menjalakan strategi yang direkomendasikan agar tetap dapat mengoperasikan bisnis secara efektif dan efisien, sehingga dapat menurunkan biaya dari kegiatan bisnis yang tidak memberikan nilai tambah untuk perusahaan. Perusahaan logistik BUMN diharapkan menjalankan bisnis sesuai dengan visi dan misi perusahaan agar dapat mencapai keunggulan maksimal di bisnis logistik dan selalu menjaga reputasi nama perusahaan. 


\section{Keterbatasan Penelitian}

1 Penelitian ini hanya berfokus pada pembahasan mengenai kondisi saat ini dari analisis lingkungan eksternal dan lingkungan internal Perusahaan logistik BUMN. Hal tersebut membuat hasil penelitian ini tidak dapat berlaku secara umum meskipun penelitian yang sama pada objek penelitian yang berbeda.

2 Penelitian ini juga memiliki keterbatasan berupa dapat memunculkan bias pada penelitian ini dikarenakan keterbatasan pemahaman peneliti secara mendalam mengenai kondisi dari lingkungan internal perusahaan. Pembiasan yang muncul akibat tersebut bisa menjadi bahan evaluasi oleh Perusahaan logistik BUMN sebagai pihak yang lebih mengenal kondisi perusahaan secara keseluruhan.

3 Penelitian ini juga memiliki keterbatasan berupa waktu wawancara oleh para informan untuk dapat tatap muka secara langsung. Kondisi tersebut membuat peneliti menggunakan media teknologi untuk mendapatkan informasi dari informan.

\section{Saran}

Berdasarkan simpulan dan implikasi praktis yang telah diuraikan sebelumnya, maka terdapat saran-saran yang diajukan sebagai masukan dan pertimbangan bagi Perusahaan logistik BUMN di antaranya:

1. Secara berkala melakukan analisis eksternal Perusahaan logistik BUMN, agar hasil analisis yang digunakan sebagai basis dari strategi bersaing perusahaan tetap up to date dan sesuai dengan kenyataan yang dihadapi dilapangan.

2. Analisis internal yang dilakukan haruslah merupakan analisis internal yang bertujuan untuk meningkatkan kinerja perusahaan sehingga haruslah dilakukan seobjektif mungkin dan dilakukan pula secara berkala sesuai dengan kebutuhan.

3. Strategi bersaing Perusahaan logistik BUMN memerlukan tindak lanjut berupa program kegiatan sebagai penjabaran strategi yang telah dihasilkan oleh analisis dan pelaksanaan program kegiatan yang konsisten merupakan tujuan akhir yang akan dicapai dengan strategi bersaing demi pencapaian kinerja Perusahaan logistik BUMN yang lebih optimal.

4. Peneliti selanjutnya yang akan membahas topik ini disarankan untuk bisa memiliki akses untuk mewawancarai jajaran Direksi. Tujuannya agar dapat mengetahui lebih banyak informasi mengenai bisnis logistik yang ada di Indonesia dan yang dijalankan oleh perusahaan.

\section{Bibliography}

Al-Hader, M. R. (2009). Smart city components architecture. Intelligence, Modelling and Simulation. (Brno, Czech Republic.

Al-Hader, M. R. (2009). SOA of smart city geospatial management. In Proceedings of the 3rd UKSim European Symposium on Computer Modeling and Simulation . (Athens, Greece.

Anderson, G. \&. (1998). Smart growth in our future? In Urban Land Institute (Ed.), . Dalam ULI on the Future: Smart Growth (hal. 4-11). Washington, DC: Washington, DC.

Cooper, D. R., \& Schindler, P. (2014). Business Research Methods. Singapore: McGraw-Hill Book.

Frost, \& Sullivan. (2014, Januari 4). Prediksi Frost \& Sullivan Mengenai Industu Logistik Indonesia yang akan tumbuh 14,7\% untuk mencapai Rp 1,816 triliun di tahun 2014. 
Diambil kembali dari http://www.frost.com/prod/servlet/pressreleaase.pag?docid=290094205\#

Wibowo, D. W. (2017, Juni 12). Bisnis Logistik, Peluang atau tantangan. Diambil kembali dari http://ali.web.id/press release.php?id=37 